\title{
Effects of carbon dioxide insufflation on anastomosis remodeling at a carotid artery site in rabbits
}

\author{
Tuğra Gençpınar ${ }^{1}$, Gökmen Akkaya², Çağatay Bilen ${ }^{2}$, Pınar Akokay $^{3}$, Osman Yılmaz $^{4}$, Hudai Çatalyürek ${ }^{1}$ \\ ${ }^{1}$ Department of Cardiovascular Surgery, School of Medicine, Dokuz Eylul University, Izmir, Turkey \\ ${ }^{2}$ Department of Cardiovascular Surgery, School of Medicine, Ege University, Izmir, Turkey \\ ${ }^{3}$ Department of Histology and Embryology, School of Medicine, Dokuz Eylul University, Izmir, Turkey \\ ${ }^{4}$ Department of Experimental Animal Laboratory, School of Medicine, Dokuz Eylul University, Izmir, Turkey
}

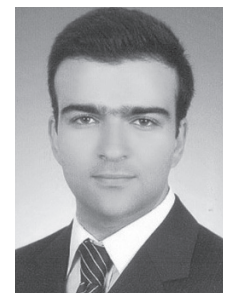

Kardiochirurgia i Torakochirurgia Polska 2018; 15 (3): 170-175

\begin{abstract}
Introduction: Use of carbon dioxide $\left(\mathrm{CO}_{2}\right)$ insufflation (CDI) on the surgical field during heart surgery has become widespread, and in some units routine.

Aim: To assess the effects of CDI on endothelial dysfunction in a carotid artery model in rabbits.

Material and methods: Twelve randomly selected rabbits were divided into two groups. Right carotid arteries of the animals were transected and sutured with running suture technique. Then, $1 \mathrm{l} / \mathrm{min} \mathrm{CO}_{2}$ insufflation was initiated with a $45^{\circ}$ angle. In the control group, the anastomotic field was irrigated with $0.1 \mathrm{ml} / \mathrm{s}$ flow of $0.9 \%$ saline. At day 28 , the carotid artery segments were removed and prepared for histological specimens. Results: In the cross-sections of the control group vessel samples, thickening of the tunica intima was observed. Scoring the quantity of endothelial nitric oxide synthase (e-NOS) and $\alpha$-smooth muscle actin ( $\alpha$-SMA) positive staining revealed a nonsignificant difference between the experimental groups $(p=0.07)$. In the $\mathrm{CO}_{2}$ group, the intimal hyperplasia $(p=0.2)$ and the thickness of the tunica media $(p=0.2)$ were indistinguishable when compared to the control group. The mean luminal diameters and luminal areas of the experimental groups were all evaluated by histomorphometry and a significant differences was found between luminal areas $(p=0.016)$. On the other hand, no significant difference was found between mean luminal diameters ( $p=0.055)$.

Conclusions: Our study indicated that CDI can affect endothelial cell damage and the mean luminal diameters.
\end{abstract}

Key words: carbon dioxide insufflation, carotid artery, intimal hyperplasia, endothelial damage.

\section{Streszczenie}

Wstęp: Zastosowanie insuflacji dwutlenkiem węgla (CDI) w chirurgii serca jest szeroko rozpowszechnione, a na niektórych oddziałach stanowi rutynowy zabieg.

Cel: Ocena wpływu CDI na zaburzenia czynności śródbłonka naczyniowego w modelu tętnicy szyjnej u królików.

Materiał i metody: Dwanaście losowo wybranych królików podzielono na dwie grupy. Prawe tętnice szyjne zwierząt przecięto w poprzek i zszyto szwem ciągłym. Następnie rozpoczęto insuflację z przepływem $1 \mathrm{l} / \mathrm{min} \mathrm{CO}_{2}$ pod kątem $45^{\circ}$. W grupie kontrolnej pole anastomotyczne zostało przepłukane 0,9\% solą fizjologiczną z przepływem 0,1 ml/s. W 28. dniu usunięto odcinki tętnicy szyjnej i przygotowano próbki do badań histologicznych.

Wyniki: W przekroju poprzecznym próbek naczyń grupy kontrolnej zaobserwowano pogrubienie warstwy wewnętrznej ściany naczynia. Pomiar ilości endotelialnej syntazy tlenku azotu (eNOS) i dodatni wynik barwienia $\alpha$-aktyny mięśni gładkich ( $\alpha$-SMA) uwidocznity brak istotnej różnicy między grupami $(p=0,07)$. W grupie $\mathrm{CO}_{2}$ hiperplazja błony wewnętrznej $(p=0,2)$ i grubość warstwy środkowej ściany naczynia $(p=0,02)$ nie różniły się $w$ porównaniu z grupą kontrolną. Średnie średnice światła naczyń i pola powierzchni światła naczyń w obu grupach oceniono w badaniach histomorfometrycznych; istotne różnice wystąpiły między polami powierzchni światła $(p=0,016)$. Nie stwierdzono jednak istotnych różnic między średnimi średnicami światła naczyń ( $p=0,055)$.

Wnioski: W badaniu wykazano, że CDI może mieć wpływ na uszkodzenie komórek śródbłonka i średnią średnicę światła naczyń.

Słowa kluczowe: insuflacja dwutlenkiem węgla, tętnica szyjna, hiperplazja błony wewnętrznej, uszkodzenie śródbłonka. 


\section{Introduction}

Insufflation of carbon dioxide $\left(\mathrm{CO}_{2}\right)$ to the operative field has been used to prevent air embolisms and keep the surgical field bloodless during coronary artery anastomosis in cardiac surgery. Carbon dioxide blowing technique is simple to use without any major adverse effect or additional cost. However, a potentially harmful effect of carbon dioxide insufflation on postoperative endothelial dysfunction remains unproven in clinical trials. In addition, the damage mechanism responsible for this effect has not been elucidated. In the literature, data on outcomes of the effect of CDI on the surgical field are limited.

Arterial anastomosis models demonstrated that the main reasons for lumen stenosis are smooth muscle cell proliferation and intimal damage [1-3]. The pathological cause of restenosis and endothelial cell proliferation is migration of proliferated smooth muscle cells from media to intima [3]. When intimal damage develops, platelets coat the damaged area and release mitogenic growth factors [3]. Therefore, the proliferated smooth muscle cells migrate and cause intimal hyperplasia [4]. Studies on endothelial cell proliferation have demonstrated that the re-endothelialization was complete by day 14 [5]. The choice of surgical procedure is critical in the presence of vascular restenosis or in complex pathological settings such as arterial thrombosis where the atherosclerotic plaque plays a fundamental role.

\section{Aim}

The aim of this study was to evaluate the effects of $\mathrm{CO}_{2}$ insufflation and endothelial damage during a rabbit carotid artery model. In addition, it can demonstrate how to avoid endothelial dysfunction in coronary artery bypass surgery (CABG) induced by $\mathrm{CO}_{2}$ insufflation to the coronary vessel, owing to its potentially harmful effect. Establishment of an animal model with $\mathrm{CO}_{2}$ blowing over the surgical field in a carotid artery site would be useful for better understanding of the immunohistochemistry in human patients.

\section{Material and methods}

This randomized, controlled, interventional experimental study was conducted at the Animal Laboratory and Research Center of Dokuz Eylul University Faculty of Medicine with the approval of the Ethics Committee for Animal Research on 3 March 2015 with the protocol number $06 / 2015$. All procedures were performed according to the Guide for the Care and Use of Laboratory Animals (Institute for Laboratory Animal Resources, National Academy of Sciences, Washington, DC, United States). The rabbits were given a 12 -h dark/light cycle at temperature $24 \pm 2^{\circ} \mathrm{C}$ and humidity $55-60 \%$, and were maintained on ad libitum diets throughout the experiments.

\section{Surgical procedure}

The experiment was performed on 12 male rabbits (weighing: 2-3 kg; mean age: 11 weeks). The rabbits were divided into two groups randomly. Before the surgical procedure, intramuscular anesthesia was administered using ketamine hydrochloride (50 mg/kg, Pfizer, Istanbul, Turkey) and xylazine $(5 \mathrm{mg} / \mathrm{kg}$, Bayer Turk Kimya Sanayi, Istanbul, Turkey). Moreover, cefazolin sodium (50 mg/kg, Bilim Ilac Sanayi, Istanbul, Turkey) intramuscularly was used to prevent infections. Later on, right-sided carotid arteries were transected and preanastomotic anticoagulation initiated with intravenous injection of $150 \mathrm{U} / \mathrm{kg}$ heparin. The suture line was made with 7/0 polypropylene via running sutures. In the treatment group, $1 \mathrm{l} / \mathrm{min} \mathrm{CO}_{2}$ was blown at a $45^{\circ}$ angle from $10 \mathrm{~cm}$ height with a standard flowmeter and gas insufflation cannula (Novatech aspirator microvac $2 \times 70 \mathrm{~mm}$ ) for approximately $5 \mathrm{~min}$ during the anastomosis process. In the control group, the carotid arteries were dissected, transected and restored in a similar fashion and the anastomotic field was irrigated with $0.1 \mathrm{ml} / \mathrm{s}$ flow of $0.9 \%$ saline solution from $10 \mathrm{~cm}$ height and a $45^{\circ}$ angle for $5 \mathrm{~min}$. There were no complications perioperatively. Following surgery, all rabbits were euthanized at the $28^{\text {th }}$ day and the carotid artery segments were removed and prepared for histological dyeing.

\section{Histopathological evaluation}

Carotid artery segments were removed and fixed in 10\% neutral buffered formalin, dehydrated in a graded series of isopropyl alcohol (60\% to $100 \%$ ) and followed by xylol before being embedded in paraffin. Later on, $5 \mu \mathrm{m}$ sections were taken with a rotary microtome (RM 2255, Leica Instruments, Nussloch, Germany) on poly-L lysine coated slides. The specimens were stained with hematoxylin and eosin (H + E, Surgipath, 01562E, Bretton, Cambridgeshire). Histomorphologic and morphometric measurements were evaluated with the images which were obtained from the selected areas and analyzed via a computer-assisted image analyzer system consisting of a microscope (Olympus BX-51, Tokyo, Japan) equipped with a high resolution video camera (Olympus, DP70, Japan). Aiming at further immunohistochemical examination, the specimens were also stained with endothelial nitric oxide synthase (eNOS) and $\alpha$-smooth muscle actin ( $\alpha$-SMA). Following these dyeing processes, all images were digitally photographed and examined via a computerized video camera based image analysis system (UTHSCA Image Tool software version 3.0, University of Texas Health Science Center, San Antonio, TX, USA). The luminal diameters, luminal areas, and intima and media thickness were all measured and the groups were compared in terms of these parameters.

\section{Statistical analysis}

Direction and significance of the association between variables were evaluated by the Mann-Whitney U-test. A $p$ value less than 0.05 was accepted as the significance level. In all calculations and statistical analyses, SPSS 15.0 (SPSS Inc, Chicago, IL, USA) and Excel (Microsoft, USA) software was used. Semiquantitative immune scoring variables were expressed as the mean \pm standard deviation. 


\section{Results}

All histochemical and histomorphological analyses described above were performed by two investigators blind to rabbits' treatment. All carotid artery lumens of the rabbits were patent. When carotid artery segments were investigated, a difference in the thickness of the tunica media and the adventitia was seen between groups (Fig. 1). Scoring the quantity of e-NOS and $\alpha$-SMA positive staining revealed a nonsignificant difference between the experimental groups (in the Mann-Whitney $U$-test, $p=0.07$ ) (Fig. 2). The carotid arteries' mean intima thickness $(\mu \mathrm{m})$ was 25.8 (6.07$26.70 \mu \mathrm{m})$ in the $\mathrm{CO}_{2}$ group. It was $16.66(13.75-44.46 \mu \mathrm{m})$ in the control group. The carotid arteries mean media thickness $(\mu \mathrm{m})$ was $150.2(117.38-171.26 \mu \mathrm{m})$ in the $\mathrm{CO}_{2}$ group. It was $133.23(127.65-179.02 \mu \mathrm{m})$ in the control group. In the $\mathrm{CO}_{2}$ group, the intimal hyperplasia $(p=0.2)$ and the thickness of the tunica media $(p=0.2)$ were indistinguishable when compared to the control group. The carotid arteries' mean lumen diameter $(\mu \mathrm{m})$ was $838.62(535.63-885.55 \mu \mathrm{m})$ in the $\mathrm{CO}_{2}$ group. It was $711.02(586.37-950.69 \mu \mathrm{m})$ in the control group. The carotid arteries' mean lumen area $\left(\mu \mathrm{m}^{2}\right)$ was $518252.99\left(142604.2-517199.2 \mu \mathrm{m}^{2}\right)$ in the $\mathrm{CO}_{2}$ group. It was $260593.06\left(254913.4-656958.0{\mu m^{2}}^{2}\right)$ in the control group The mean luminal diameters and luminal areas of the experimental groups were all evaluated by histomorphometry and a significant difference was found between luminal areas $(p=0.016)$. On the other hand, no significant difference was found between mean luminal diameters ( $p=0.055)$ (Table I).

\section{Discussion}

The present study demonstrated the effects of washing with saline solution and carbon dioxide gas blowing techniques on the cellular and ultrastructural changes and intimal hyperplasia in a rabbit carotid artery model. The experimental study model was performed by surgical intervention of the carotid artery followed by transection and restoration with side-by-side suture technique.

Beating heart coronary bypass surgery is often bloody because of blood from native arteries. Anastomosis quality must be maintained during the CABG operation. Different methods to ensure sufficient visibility in the surgical field are used for the anastomosis quality. These methods are intra-coronary shunt placement, aspiration and drying, washing with saline solution or $\mathrm{CO}_{2}$ blowing techniques. Saline irrigation may not be enough to clean the area of the anastomosis. On the other hand, application of intracoronary shunts and occluders is difficult. Also, that can cause stress in the coronary artery wall and have a risk of coronary endothelial dysfunction. Gas blowing technique is the most effective method to maintain a bloodless surgical field, but this technique has some risks following physical stimuli $[6,7]$. The importance of intimal hyperplasia, restenosis and endothelial proliferation processes is obvious in
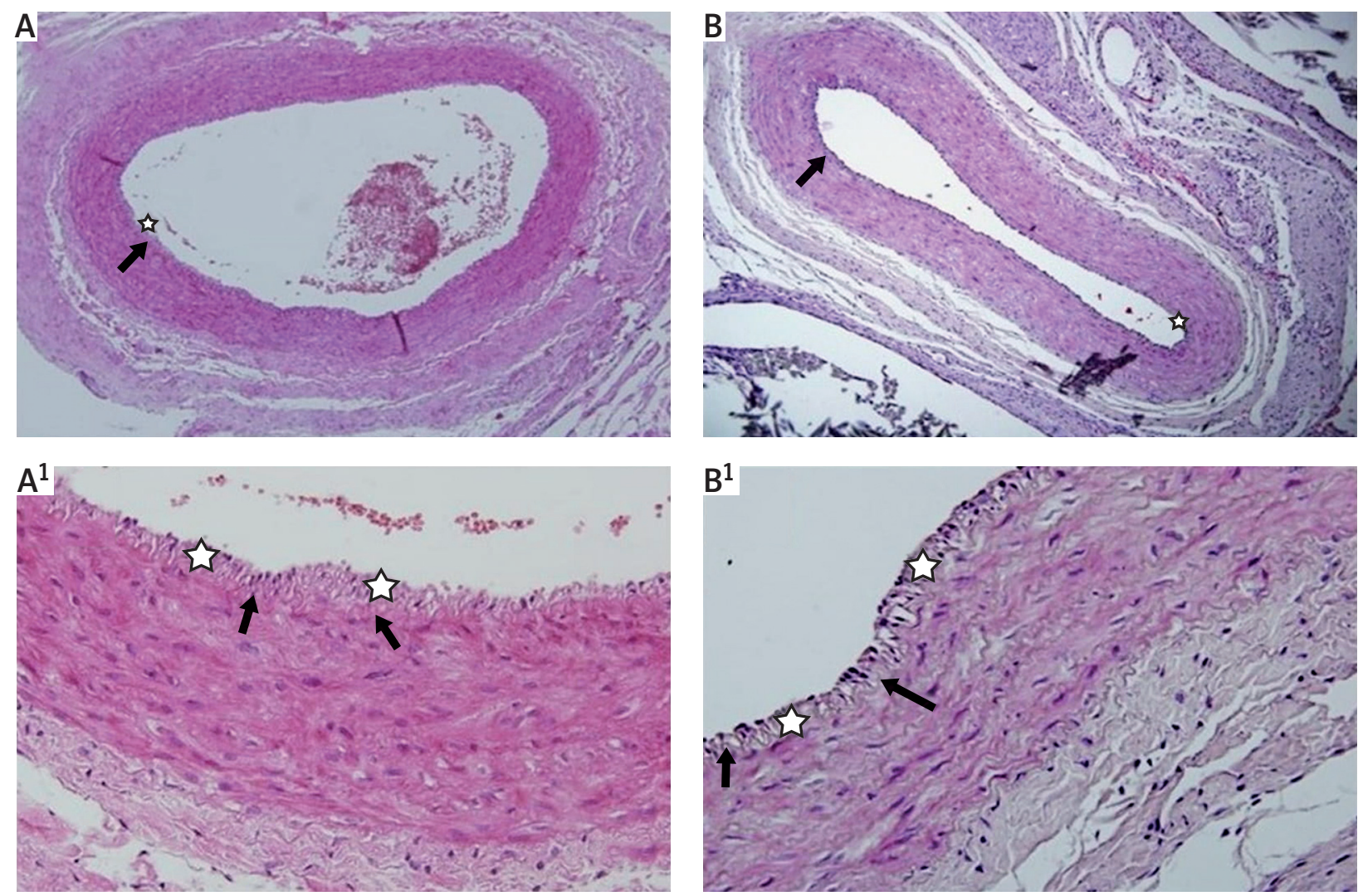

Fig. 1. Histological sections of groups (hematoxylin + eosin stain, 10x and 40x): A - treatment group, 10x; A $^{1}$ treatment group, 40x, B - control group, 10x, $\mathbf{B}^{1}$ - control group, 40x. Internal elastic lamina marked with arrow and intimal hyperplasia marked with star 

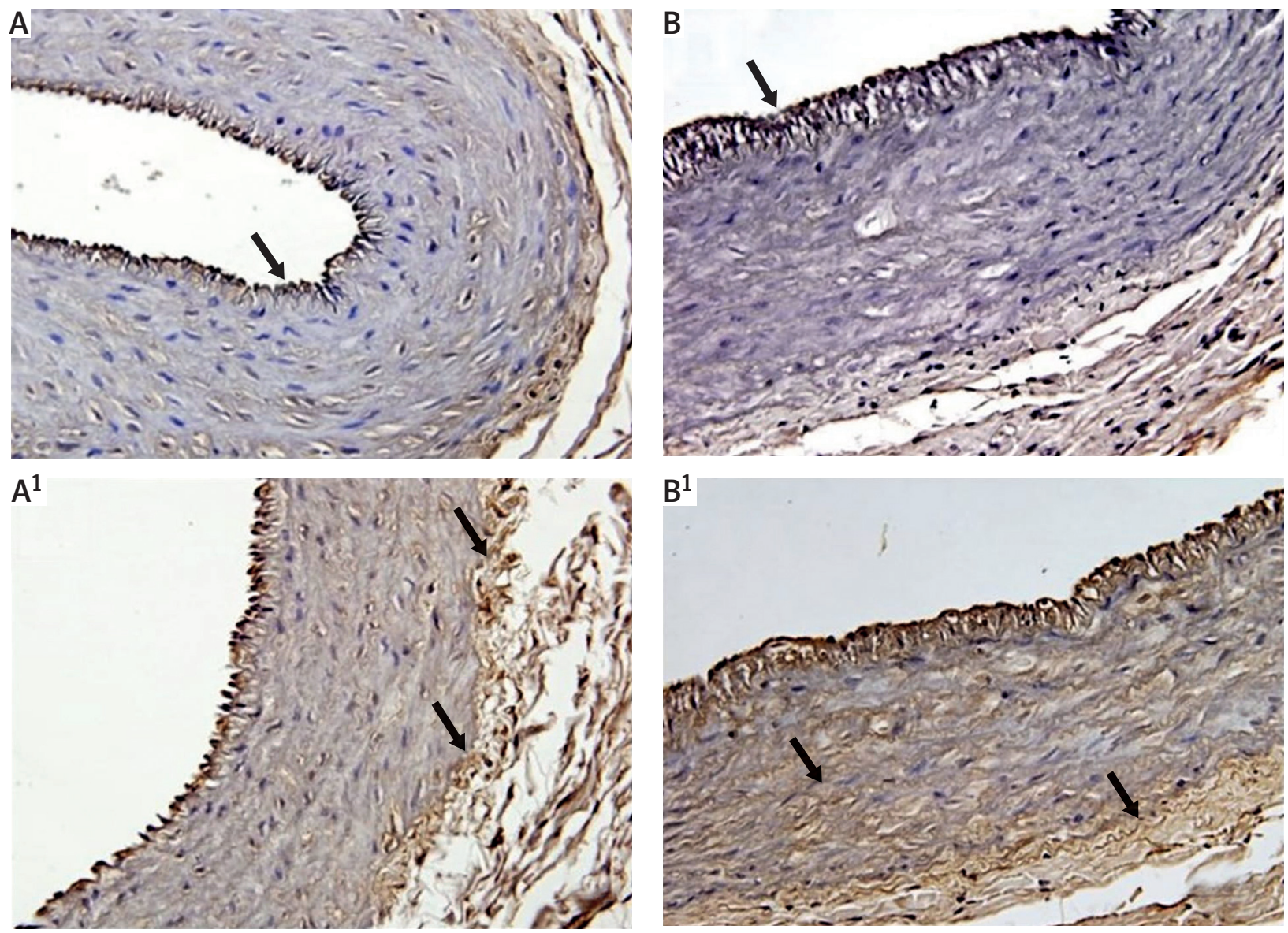

Fig. 2. Histological sections of groups (e-NOS and $\alpha$-SMA staining, 40x): A - treatment group, 10x, $\mathrm{A}^{1}$ - treatment group, 40x, e-NOS staining; B - control group, 10x, B $^{1}$ - control group, 40x, $\alpha$-SMA staining. Intimal hyperplasia marked with arrow

Table I. Comparison of mean lumen diameters and lumen area, mean intima/media thickness area values

\begin{tabular}{|c|c|c|c|c|}
\hline \multicolumn{2}{|l|}{ Parameter } & \multirow{2}{*}{$\begin{array}{c}\text { Treatment group }\left(\mathrm{CO}_{2}\right) \\
838.62\end{array}$} & \multirow{2}{*}{$\begin{array}{c}\text { Control group (Saline) } \\
711.02\end{array}$} & \multirow{2}{*}{$\begin{array}{c}P \text {-value } \\
0.055\end{array}$} \\
\hline Lumen diameter $[\mu \mathrm{m}]$ & Mean & & & \\
\hline & Median & 881.40 & 730.90 & \\
\hline & Std. deviation & 132.11 & 103.13 & \\
\hline \multirow[t]{3}{*}{ Luminal areas $\left[\mu \mathrm{m}^{2}\right]$} & Mean & 518252.99 & 260593.06 & 0.016 \\
\hline & Median & 546820.70 & 193291.21 & \\
\hline & Std. deviation & 150864.68 & 150755.67 & \\
\hline \multirow[t]{3}{*}{ Intima thickness [ $\mu \mathrm{m}]$} & Mean & 25.80 & 16.66 & 0.2 \\
\hline & Median & 23.99 & 17.59 & \\
\hline & Std. deviation & 11.77 & 7.98 & \\
\hline \multirow[t]{3}{*}{ Media thickness $[\mu \mathrm{m}]$} & Mean & 150.20 & 133.23 & 0.2 \\
\hline & Median & 144.93 & 137.06 & \\
\hline & Std. deviation & 20.75 & 13.53 & \\
\hline
\end{tabular}

cardiovascular surgery. Impairment of vascular endothelial integrity occurs on the basis of arterial thrombosis. Accordingly, it continues to be promoted by thrombosis.

Carbon dioxide blowing can be performed continuously or intermittently. A standard method is undefined. This approach is used to clean the surgical field during coronary artery anastomosis. According to the experience of the sur- gical team it is important to use different methods. Gas flow rate, catheter type and thickness, the distance of the anastomosis, and the differences in execution time can cause endothelial dysfunction in atherosclerotic vessels. Endothelial vascular tonus regulation can effect intimal hyperplasia [3-5]. Platelet adhesion to damaged endothelium causes aggregation and degranulation. Platelets are 
released from platelet-derived growth factor dependent migration to the intima of smooth muscle cells and proliferation occurs. In addition, P-selectin, ICAM-I, and GP-IIb/ Illa cell adhesive factors can be secreted by damaged endothelium [6-8]. Thus, by contact of the blood components can cause aggregation and thrombosis.

Clinically, carbon dioxide insufflation on the surgical field was used as early as 1958 by Nichols et al. They demonstrated that carbon dioxide emboli absorbed faster than air emboli. Insufflation of $\mathrm{CO}_{2}$ to de-air the heart and great vessels' wound markedly decreases the incidence of microemboli. Nowadays, the interest in minimally invasive heart surgery where de-airing techniques have to be more effective has led to resurgence in the interest in and use of $\mathrm{CO}_{2}$ field flooding. Also, the interest in cardiac surgery is to prevent bleeding on the surgical field during coronary artery anastomosis. Altogether 205 articles were found using the reported search about $\mathrm{CO}_{2}$ insufflation, and few of them were used to answer the clinical question of CDI on endothelial damage.

Burfeind et al. reported that high-flow carbon dioxide gas insufflation has a harmful effect on coronary endothelium and may cause both early and late-term graft failure [9]. Moreover, Alves et al. found a strong correlation between flow rate and endothelial injury of the internal mammary artery in their experimental model in goats [10].

As shown in another study, Martens et al. demonstrated that they could deliver $\mathrm{CO}_{2}$ at up to $10 \mathrm{l} / \mathrm{min}$ without causing an increase in arterial $\mathrm{PCO}_{2}$ or acidosis to determine the optimal technique for the delivery and amounts of $\mathrm{CO}_{2}$ [7]. They measured arterial blood gasses. Martens et al.' prospective study of $\mathrm{CO}_{2}$ insufflation compared to conventional de-airing techniques showed no statistically significant differences between the two groups in terms of mortality or neurocognitive function [6]. Otherwise, neurocognitive test outcomes did not reveal any advantages of $\mathrm{CO}_{2}$ field flooding in two studies. Ganguly et al. recommend that $\mathrm{CO}_{2}$ insufflation be performed in all open heart surgery cases to bring down the incidence of neurocognitive dysfunction. Also, they reported no requirement of major paraphernalia or additional costs with this technique [6-18].

In this content, the aim of our study was to evaluate the effects of $\mathrm{CO}_{2}$ insufflation on the cellular and ultrastructural changes occurring in the carotid artery model in animals. e-NOS is known to be primarily responsible for the generation of NO in the vascular endothelium [16]. $\alpha$-SMA is known to play a crucial role in fibrogenesis and correlates with the activation of myofibroblasts [17]. Also, SMA has an important role in fibrogenesis and myofibroblast generation [17]. The endothelium plays a major role in regulating usual blood vessel physiology. Intimal hyperplasia is an independent risk factor for the cardiovascular field. As a result of it, arterial elasticity and the muscle smooth muscle cell, collagen, elastic fibrils, and proteoglycans in the matrix are changed, and vessel wall injury occurs [17]. Medial thickening with effects of $\mathrm{CO}_{2}$ insufflation can be attributable primarily to improved smooth muscle cell mass, although enhanced deposition of collagen and elastin has a contributory role. Furthermore, many surgeons avoid operating on patients with I/R injury related intimal damage because of disastrous complications. In the animal model, we preferred to evaluate the effects of $\mathrm{CO}_{2}$ insufflation in order to find activation of complements and ischemia/reperfusion (I/R) injury related damage. In the cross-sections of the control group vessel samples, thickening of the tunica intima was noted. When the other parts of the aorta were investigated, there was an increase in the thickness of the tunica media and prominent thickening in the adventitia in this group. Scoring the quantity of e-NOS and $\alpha-S M A$ positive staining revealed a nonsignificant difference between the experimental groups (in the Mann-Whitney $U$ test, $p=0.07)$. In the $\mathrm{CO}_{2}$ group, the intimal hyperplasia $(p=0.2)$ and the thickness of the tunica media were indistinguishable when compared to the control group (Fig. 1 A, B). Also, the mean luminal diameters and luminal areas of the experimental groups were all evaluated by histomorphometry and a significant difference was found between lumen areas $(p=0.016)$. On the other hand, no significant difference was found between mean luminal diameters $(p=0.055)$. With the help of these findings, we found that $\mathrm{CO}_{2}$ gas insufflation has a prominent destructive effect on luminal areas of the experimental groups. Because of this evidence, we think that CDI causes endothelial cell damage. Vascular endothelium is extremely sensitive to physical stimulation because of CDI.

\section{Study limitations}

The primary limitation of our study was the lack of molecular data. We plan to perform our study on a higher budget and include immunohistochemistry data and oxidative stress parameters. In our opinion, further studies should be conducted to compare the effects of carbon dioxide insufflation on the surgical field during heart surgery.

\section{Conclusions}

Carbon dioxide gas insufflation on the surgical field in an animal model seems to have harmful adverse effects on the mean luminal areas. In our opinion there is still a need for comparative studies to assess the endothelial effects of $\mathrm{CO}_{2}$ insufflation in patients undergoing peripheral artery disease and coronary artery disease.

\section{Disclosure}

The authors report no conflict of interest.

\section{References}

1. Sun Y, Ji B, Zhu X, Zheng Z. Efficacy of carbon dioxide insufflation for cerebral and cardiac protection during open heart surgery: a systematic review and meta-analysis. Artificial Organs 2013; 37: 439-446.

2. Chaudhuri K, Storey E, Lee GA, Bailey M, Chan J, Rosenfeldt FL, Pick A, Negri J, Gooi J, Zimmet A, Esmore D, Merry C, Rowland M, Lin E, Marasco SF. Carbon dioxide insufflation in open-chamber cardiac surgery: a double-blind, randomized clinical trial of neurocognitive effects. J Thorac Cardiovasc Surg 2012; 144: 646-653. 
3. Karaarslan K, Abud B, Albayrak G, Aykut K, Ergür BU, Silistreli E. The effect of resveratrol on intimal hyperplasia and endothelial proliferation of rabbit carotid artery anastomosis. Interact Cardiovasc Thorac Surg 2014; 20: 15-20.

4. Guzeloglu M, Aykut K, Albayrak G, Atmaca S, Oktar S, Bagriyanik A, Hazan E. Effect of tadalafil on neointimal hyperplasia in a rabbit carotid artery anastomosis model. Ann Thorac Cardiovasc Surg 2013; 19: 468-474.

5. Martens S, Neumann K, Sodemann C, Deschka H, Wimmer-Greinecker G, Moritz A. Carbon dioxide field flooding reduces neurologic impairment after open heart surgery. Ann Thorac Surg 2008; 85: 543-547.

6. Martens S, Dietrich M, Wals S, Steffen S, Wimmer-Greinecker G, Moritz A Conventional carbon dioxide application does not reduce cerebral or myocardial damage in open heart surgery. Ann Thorac Surg 2001; 72: 1940-1944.

7. Martens S, Dietrich M, Doss M, Wimmer-Greinecker G, Moritz A. Optimal carbon dioxide application for organ protection in cardiac surgery. J Thorac Cardiovasc Surg 2002; 124: 387-391.

8. Lüscher TF, Tanner FC, Tschudi MR, Noll G. Endothelial dysfunction in coronary artery disease. Annu Rev Med 1993; 44: 395-418.

9. Burfeind WR Jr, Duhaylongsod FG, Annex BH, Samuelson D. High-flow gas insufflation to facilitate MIDCABG: effects on coronary endothelium. Ann Thorac Surg 1998; 66: 1246-1249.

10. Alves ELM, Stolf NAG, de Almeda ECS, Moreira LFP, Junior FSF, Gutierrez PS Analyses of the immediate effect of $\mathrm{CO}_{2}$ flow on vascular endothelium in goats. Braz J Cardiovasc Surg 2006; 21: 295-303.

11. Okazaki Y, Takarabe K, Murayama J, Suenaga E, Furukawa K, Rikitake K, Natsuaki M, Itoh T. Coronary endothelial damage during off-pump CABG related to coronary-clamping and gas insufflation. Eur J Cardiothorac Surg 2001; 19 : 834-839.

12. Skidmore KL, Jones C, DeWet C. Flooding the surgical field with carbon dioxide during open heart surgery improves segmental wall motion. J Extra Corpor Technol 2006; 38: 123-127.

13. Bakaeen FG, Chu D, Kelly RF, Holman WL, Jessen ME, Ward HB. Perioperative outcomes after on- and off-pump coronary artery bypass grafting. Tex Heart Inst J 2014; 41: 144-151.

14. Park CS, Kwak JG, Lee C, Lee CH, Lee SK, Kim YL. Near-infrared spectroscopy as a possible device for continuous monitoring of arterial carbon dioxide tension during cardiac surgery. Perfusion 2011; 26: 524-528.

15. Nichols H, Morse P, Hirose T. Coronary and other air embolization occurring during open cardiac surgery. Surgery 1958; 43: 236-244.

16. Fish JE, Marsden PA. Endothelial nitric oxide synthase: insight into cell-specific gene regulation in the vascular endothelium. Cell Mol Life Sci 2006; 63: 144-162.

17. Ergür BU, Cilaker Mıcılı S, Yılmaz O, Akokay P. The effects of alpha-lipoic acid on aortic injury and hypertension in the rat remnant kidney (5/6 nephrectomy) model. Anatol J Cardiol 2015; 15: 443-449.

18. Ganguly G, Dixit V, Patrikar S, Venkatraman R, Gorthi SP, Tiwari N. Carbon dioxide insufflation and neurocognitive outcome of open heart surgery. Asian Cardiovasc Thorac Ann 2015; 23: 774-780. 